\title{
Effect of Ajowan Seeds as Safe Inhibitor on the Corrosion of Steel in 2.0 M Sulfuric Acid
}

\author{
Aisha M. Al-Turkustani \\ King Abd El-Aziz University, Girls College of Education, Chemistry Department, Jeddah, KSA \\ E-mail: A.M.Turkustani@hotmail.com
}

\begin{abstract}
s
Corrosion inhibition of steel in sulphuric acid by aqueous extract of Ajowan (carom) seeds has been studied using chemical (HE and ML) and electrochemical (EIS and PDP) measurements at $30^{\circ} \mathrm{C}$. The results indicated that Ajowan extract inhibit the corrosion process in $2.0 \mathrm{M} \mathrm{H}_{2} \mathrm{SO}_{4}$ and the inhibition efficiency increase as concentration increased. Impedance studies showed that the charge transfer controls the dissolution mechanism of steel across the phase boundary in the absence and the presence of the inhibitor and potentiodyanamic polarization results indicated that Ajowan seeds act as mixed type inhibitor. The inhibition efficiency obtained from various employed methods is approximately in good agreement. Adsorption process of Ajowan molecules on steel surface is spontaneous and it obeys the Freundlish adsorption isotherm.
\end{abstract}

Keywords: Ajowan plant, Corrosion, Inhibition, Steel, Acids, Sulphuric acid

\section{Introduction}

Steel is considered to be the main constructing materials in industry. There is a great need to protect steel from dissolution by using corrosion inhibitors. Acid scaling and corrosion inhibitors find wide applications in the industrial field as a component for industrial equipments, and in acidization of oil wells (F. Bentiss, M. Traisnel, H. Vezin and M. Lagrenee, 2000).

Many studies have been made on the corrosion inhibition of steel in acid media (B. Abd-El Nabey, E. Khamis, G. Thompson and J. Hames, 1986) (E. Stupnisek-Lisac, K. Salajster and J.Furac, 1988) (S. Arab and B. Abd-El Nabey,1991) (E. E. Ebenso, N. O. Eddy and A. O. Odiongenyi, Portugaliae, 2009) (A. Y. Musa, A. A. H. Kadhum, M. S. Takriff, A. R. Daud and S. K. Kamarudin,2009). Many of the commonly used inhibitors are organic compounds that can be hazardous to health if they are allowed to contaminate the environment.

Due to the currently imposed environmental requirements for friendly corrosion inhibitors, there is a growing interest in the use of natural products such as leaves or seeds extract. Natural plant extract represent a category of non- toxic and have safe chemical compounds that can be extracted by simple procedures with low cost and used as corrosion inhibitors.

Environmental friendly inhibitors have attracted several researchers. Natural products are nontoxic, biodegradable and readily available. They have been used widely as inhibitors. Natural products such as caffeine (S. Rajendran, S. Vaibhavi, N. Anthony and D.C. Trivedi, 2003)( S. Rajendran, A. John Amalraj, M. Jasmine Joice, Noreen Anthony, D.C.Trivedi and M. Sundaravadiveelu, 2004) have been used as inhibitors. Corrosion inhibition of steel by plant extracts in acidic media has been reported (A.M. Abdel-Gaber, B.A. Abd-El-Nabey, I.M. Sidahmed, A.M. El-Zayaday, M. Saadawy, 2006) (L.R. Chauhan, G. Gunesekaran, 2007) . Scale inhibiting nature of plant extracts for various kinds of metals are summarized briefly (S. Rajendran, V. Ganga Sri, J. Arockia Selvi and A.J. Amalraj, 2005). Natural compounds as corrosion inhibitors for industrial cooling systems have been studied (Aqueous extract of Rosemary leaves (M. Kliskic, J. Rado Sevic, S. Gudic and V. Katalinic,2000), Zenthoxylum - alatum (G. Gunasekaran and L.R. Chauhan, 2004) and Lawsonia (A.Y.E. Etre, M. Abdullah and Z.E.E. Tantawy, 2005)) have been used to inhibit corrosion of metals. Corrosion inhibition of iron in hydrochloric acid solutions by naturally occurring Henna has been investigated (A. Chetouani and B. Hammouti, 2003). An aqueous extract of plant material rhizome (Curcuma Longa L) powder has been used as a corrosion inhibitor for carbon steel (S. Rajendran, S. Shanmugapriya, T. Rajalakshmi and A. John Amalraj, 2005). Aqueous extracts of Onion (. Rajendran, S. Muthulakshmi, R. Rajeshwari and A. Vijitha, 2005), and rogaphis panizulata (G.O. Avwiri and F.O. Igho, 2003) have been used as corrosion inhibitors. Inhibitive action of Carcia papaya extracts on the corrosion of mild steel in acidic media and their adsorption characteristics have been studied (P.C. Okafor and E.E. Ebenso, 2007). Azadirachta indica in acid solution has good corrosion inhibitive property (E.E. Oguzie, Pig. Resin. 2006). Corrosion inhibition of carbon steel in low chloride media by an aqueous extract of Hibiscus rosa- sinensis Linn has been evaluated by mass-loss method and electrochemical studies (K. Anuradha, R. Vimala, B. Narayanasamy, J. Arockia Selvi and S. Rajendran, 2008). 
Investigation of natural inhibitors is particularly interesting because they are non-expensive, ecologically friendly/ acceptable and possess no threat to the environment.

Ajowan plant (carum), Fig.(1a and b) is organic in nature and is much used as a medical plant in Ayurvedic medicine, mainly, it helps against diseases of the digestive tract and fewer. Ajowan seeds (Fig.(1b) contain of a volatile oil which contain of Thymol (39.36\%), $\gamma$-Terpinene(30.97\%), $\quad p$-Cymene(19.47\%), $\beta$-Pinene(5.45\%), $\alpha$-Pinene(1.48\%) and Limonen (S. Nagalakshmi, N. B. Shankarya, J. P. Naik and L. J. M. Rao, 2000). Figure (2) illustrates the structures of some of the major compounds in Ajowan seeds.

The purpose of this paper is to elucidate the corrosion inhibition of steel in sulphuric acid by Ajowan seeds extract as safe and novel inhibitor.

\section{Experimental:}

\subsection{Preparation of the Plant Extract}

Stock solution of the extract of Ajowan (carum) plant were prepared by boiling $20 \mathrm{~g}$. of Ajowan seeds in $250 \mathrm{ml}$. of bi-distilled water for 1.0 hour and left all night, then it filtered and completed to $250 \mathrm{ml}$. by bi- distilled water in measuring flask. The extract then is kept the solution in refrigerator at low temperature. The concentration of all additives were expressed in $\% \mathrm{v} / \mathrm{v}$.

\subsection{Preparation of the Metal Specimen}

Commercial steel electrode with the chemical composition $0.38 \% \mathrm{C}, 0.15 \% \mathrm{Mo}, 0.50 \% \mathrm{Mn}, 0.40 \% \mathrm{Si}, 0.03 \% \mathrm{~S}$, $0.035 \% \mathrm{P}$ and $97.61 \% \mathrm{Fe}$ was used, it polished using different emery papers up to 1200 grade, washed thoroughly with bi-distilled water degreased with acetone and dried.

\subsection{Electrolyte}

The solution used were made of AR grade sulphuric acid. Appropriate concentration of acid was prepared by using bi- distilled water. The concentration range of the inhibitor (Ajowan extract) employed was varied from 1.0 to $15.0 \% \mathrm{v} / \mathrm{v}$.

\subsection{Chemical and Electrochemical Measurements}

A chemical (hydrogen evolution and mass loss) measurements were carried out as described elsewhere. (S. T. Arab and A. M. Al-Tukustani, 2002). Electrochemical (impedance and polarization) measurements were carried out using an impedance spectrum analyzer (ACM instrument) connected to a Samsung computer (Bridgemax DVD ASUS 8X) (F. Zucchi and I. H. Omar, 1985). The input signal amplitude was $10 \mathrm{mV}$ peak to peak in both high and low frequency ranges. The electrode potential was measured against silver/silver chloride electrode. A platinum foil was used as an auxiliary electrode.

The inhibition efficiency from chemical methods (Inh.HE $\%$ and Inh.MS $\%$ ) and electrochemical methods (Inh. ${ }_{\text {EI }} \%$ and Inh.p $\%$ ) were calculated from the following relations, respectively:

$$
\begin{aligned}
\text { Inh.HE } \% & =\left(1-R^{\prime} / R_{\circ}\right) \times 100 \\
\text { Inh.ML } \% & =\left(1-R^{\prime} / R_{\circ}^{\prime}\right) \times 100 \\
\text { Inh.EI } \% & =\left(1-1 / R_{c t} / 1 / R^{\circ}\right) \times 100 \\
\text { Inh.P\% } & =\left(1-I_{\text {corr. }} / I_{\text {coor. }}^{\circ}\right) \times 100
\end{aligned}
$$

where, $\mathrm{R}, \mathrm{R}_{\mathrm{o}}, \mathrm{R}^{\prime}, \mathrm{R}^{\prime}{ }_{\mathrm{o}}, \mathrm{I}_{\text {corr., }}, \mathrm{I}_{\text {corr. }}, \mathrm{R}_{\mathrm{ct}}$ and $\mathrm{R}_{\mathrm{ct}}$ are the corrosion rate, the corrosion current and the charge transfer resistance for steel in absence and presence of certain concentrations of Ajowan extract from HE, ML,EI and P methods, respectively.

\section{Results and Discussion:}

\subsection{Hydrogen Evolution and Mass Loss Study}

The corrosion rates for steel in $2.0 \mathrm{M} \mathrm{H}_{2} \mathrm{SO}_{4}$ in absence and presence of Ajowan extract were determined using hydrogen evolution (HE) and mass loss (ML) methods.

Figure (3) shows the plots of the variation of hydrogen gas evolved with time during the corrosion of steel in 2.0 $\mathrm{M} \mathrm{H}_{2} \mathrm{SO}_{4}$ at various concentrations of Ajowan extract at $30^{\circ} \mathrm{C}$.

Inspection of the plots reveals that hydrogen gas evolution commences only after an induction period, which corresponds to the time interval needed by the corrodent to break down the pre-immersion oxide film on the steel surface (M.A.Ameer, E.Khamis and G. Al-Senani, 200) (A. Y. El-Etre, 2003) (A. K. Maayta and N. A. F. Al-Rawashdeh, 2004) (A. Popova, M.Christov, S. Raicheva and E.Sokolova, 2004) (M. Abdallah, 2004) (E. E. 
Oguzie, G. N. Onuoha and A. I. Onuchukwu, 2004) (E. E. Oguzi, 2005) (E. E. Oguzi, 2006). After the induction period, the volume of evolved $\mathrm{H}_{2}$ gas varies linearly with reaction time. The plots also illustrate the decreased deflection of $\mathrm{H}_{2}$ gas evolution rate on introduction of the extract into the corrodent, indication that the Ajowan extract affords corrosion inhibition of steel in the acidic environment. The volume of $\mathrm{H}_{2}$ evolved were observed to reduce on addition of different concentrations of Ajowan extract. This indicates that Ajowan seeds extract inhibits the corrosion of steel in $2.0 \mathrm{M} \mathrm{H}_{2} \mathrm{SO}_{4}$ and suggesting that the inhibiting action was concentration dependent.

The corrosion rates obtained from HE and ML methods for the corrosion of steel in presence of different concentrations of Ajowan extract in $2.0 \mathrm{M} \mathrm{H}_{2} \mathrm{SO}_{4}$ were assessed from the slopes of the linear portions of the hydrogen evolution plots and from the relation $\left(\mathrm{R}^{`}=\left(\mathrm{W}_{1}-\mathrm{W}_{2}\right) / \mathrm{t} \times \mathrm{A}\right)$, respectively, where $\mathrm{W}_{1}$ and $\mathrm{W}_{2}$ are the weighed of steel before and after immersion, $\mathrm{A}$ is the area of steel sample and $\mathrm{t}$ is the immersion time. The corresponding values of corrosion rate for the different test solutions are given in Table (1).

The results show that the corrosion rates from HE and ML measurements decreased with increasing the extract concentration and the values of inhibition efficiency (Inh. .E $_{0} \%$ and $\mathrm{Inh}_{. \mathrm{ML}} \%$ ) increase with increasing Ajowan extract concentration (Table 1). This behavior may be attributed to the increase of the surface area covered by the adsorbed molecules of Ajowan extract with the increase in concentration of the inhibitor. In Ajowan seeds organic compounds present such as Thymol, $\gamma$-Terpinene, $p$-Cymene, $\beta$-Pinene, $\alpha$-Pinene and Limonene, atc, can easily be adsorbed on steel surface giving rise to inhibition and the inhibition may be due to their synergistic action of these compounds.

\subsection{Impedance and Potentiodynamic Polarization Study}

Nyquist diagrams over a wide range of frequency were obtained after $20 \mathrm{~min}$. immersion of steel sample in $2.0 \mathrm{M}$ $\mathrm{H} 2 \mathrm{SO} 4$ in the absence and presence of different concentrations of Ajowan extract at $30^{\circ} \mathrm{C}$ are shown in Figure (4).

As can be notice from Figure (4), the impedance diagrams obtained were not perfect semicircles, this difference has been attributed to frequency dispersion (F. Bentiss, M. Lagrenee, M. Traisnel and J. C. Hornez, 1999). The semi-circles appearance indicating a charge transfer process mainly controlling the corrosion of steel in $2.0 \mathrm{M}$ $\mathrm{H}_{2} \mathrm{SO}_{4}$ and the presence of the extract of Ajowan plant in acidic solution does not alter the mechanism of dissolution of steel surface (F. Mansfeld, M. W. Kending and S. Tsai, 1982).

The potentiodynamic polarization curves are presented in Figure (5), the corresponding polarization curves exhibit Tafel type behavior and Ajowan extract retard both anodic and cathodic processes (metal dissolving and hydrogen evolution), this appears in the displacement of Tafel lines (cathodic and anodic), i.e., Ajowan extract act as mixed type inhibitor. The electrochemical parameters obtained from impedance and polarization curves are summarized in Table (2). These include, the charge-transfer resistance $\left(\mathrm{R}_{\mathrm{ct}}\right)$ which calculated from the difference in impedance at lower and higher frequencies, as suggested by Tsura et al. (T. Tsura, S. Haruyama and B. Gijutsu, 1978) and the double layer capacitance $\left(\mathrm{C}_{\mathrm{dl}}\right)$ values which obtained from equation:

$$
\mathrm{C}_{\mathrm{d} 1}=\pi f \max _{\mathrm{ct}} / 2
$$

where $f$ is the frequency at the maximum height of the semi-circle on the imaginary axis, the corrosion potential ( $\left.\mathrm{E}_{\text {corr. }}\right)$, the corrosion current $\left(\mathrm{I}_{\text {corr. }}\right)$, the anodic and cathodic Tafel constants $\left(\mathrm{b}_{\mathrm{a}}\right.$ and $\left.\mathrm{b}_{\mathrm{c}}\right)$, for Ajowan extract .

As can be seen from Table (2), the presence of Ajowan extract enhances the value of $\mathrm{R}_{\mathrm{ct}}$ in acidic solution $2.0 \mathrm{M}$ $\mathrm{H}_{2} \mathrm{SO}_{4}$, the values of $\mathrm{R}_{\mathrm{ct}}$ increases with the increase in concentration of Ajowan extract. Also, values of double layer capacitance are decreases in the presence of extract.The decrease in $\mathrm{C}_{\mathrm{dl}}$ is suggested to be due to the adsorption of Ajowan compounds on the steel surface leading to the formation of film from acidic solution (K. O. Orubite and N. C. Oforka, 2004). It is also noted that the presence of Ajowan extract has a pronounced effect on the corrosion current and shifts the corrosion potential by $\approx 20 \mathrm{mV}$ to more negative values and it remain approximately constant by increasing the Ajowan extract concentration. Ajowan extract affects both anodic and cathodic over potentials, i.e. acting as mixed type inhibitor by forming an adsorbed layer at the metal/solution interface that decreases the available anodic and cathodic sites required for metal dissolution and hydrogen evolution, respectively.

\subsection{Inhibition Efficiency and Adsorption Isotherm}

The inhibition efficiency got from chemical (HE and ML) and electrochemical (EI and P) methods are listed in Table (3). It is clear that the inhibition efficiencies in presence of Ajowan extract increase with increasing the concentration of extract up to $5.0 \% \mathrm{v} / \mathrm{v}$. Above that level, increasing the concentration from $5.0 \% \mathrm{v} / \mathrm{v}$ to $15.0 \% \mathrm{v} / \mathrm{v}$ has a little effect on the inhibition efficiency of steel corrosion by Ajowan extract. This behavior could be 
attributed to the synergistic effect of the major chemical constituents of Ajowan extract (Fig.(2)) leading to cover anodic and cathodic sites through their oxygen function groups $(\mathrm{OH})$. The larger number of different chemical compounds for Ajowan extract (AE) may react with the steel (iron,Fe), which is firstly dissolved from the metal surface, forming organo- metallic complex such as Fe-Ajowan extract $[\mathrm{Fe}-\mathrm{AE}]^{2+}$ according to the following mechanism (G. Gunasekaran and L. R. Chauhan, 2004)

$\mathrm{Fe} \longrightarrow \mathrm{Fe}^{2+}+2 \mathrm{e}-$

$\mathrm{Fe}^{2+}+\mathrm{AE} \quad \longrightarrow \quad[\mathrm{Fe}-\mathrm{AE}]^{2+}$

where Fe-Ajowan extract, $[\mathrm{Fe}-\mathrm{AE}]^{2+}$ may be as a stable complex adsorbed over the metal surface resulting an inhibitive effect.

Figure (6) shows the relationship between inhibition efficiency (Inh.\%) and logarithm of concentration ( $\log \mathrm{C})$ of Ajowan extract in $2.0 \mathrm{M} \mathrm{H}_{2} \mathrm{SO}_{4}$ from chemical and electrochemical methods. It is clear that the results approximately in agreement but there are some difference in the values of inhibition efficiency from all methods. The difference observed can be attributed to the difference in measurement methods and to the fact that the chemical methods give average corrosion rates, whereas electrochemical methods give instantaneous corrosion rates (S. Muralidharan, B. R. Babu and S. V. Iyer, 1996). As can be readily seen from Figure (6), all plots have the form of $S$-shaped adsorption isotherm. This indicates that corrosion inhibition process occurs by adsorption. To know the mechanism of electrochemical reaction, it is necessary to select the appropriate adsorption isotherm. It is found from the results in Figure (7) that the adsorption of Ajowan extract followed the Freundlish adsorption isotherm using the following equation (B. Berge, K. Grijotheim, C. Kronhn, R. Ncumann and K. Torkiep, 1976) (M. Kliskic, J. Radosevic, S. Gudic and V. Katalinik, 2000):

$$
\begin{aligned}
\Theta & =K C^{n} \\
\log \theta & =\log K+n \log C
\end{aligned}
$$

where, $0<\mathrm{n}<1, \Theta$ is the degree of surface coverage for different concentrations of Ajowan extract, $\mathrm{C}$ is the Ajowan extract concentration and $\mathrm{K}$ is the bonding constant (equilibrium constant) of the adsorption process.

It is clear from Figure (7), that the relation between $\log \theta$ vs. $\log C$ give a straight lines from all methods which indicates that the adsorption of Ajowan extract molecules on the steel surface obey Freundlish isotherm.

The standard free energies for adsorption was calculated using the equation (8):

$$
\log \mathrm{K}=\log (1 / 55.5)-\Delta \mathrm{G}_{\text {ads. }}^{\mathrm{o}} \quad / 2.303 \mathrm{RT}
$$

where the numerical value (1/55.5) stands for molarities of water, the calculated values of -

$\Delta \mathrm{G}^{0}{ }_{\text {ads. }}$ are $6.553,7.958,7.055$ and $8.029 \mathrm{~kJ} . / \mathrm{mol}$. from HE, ML, EI and P methods, respectively

which are low values, indicating that the interaction between Ajowan molecules and the steel surface is found by the physical adsorption which is the result of electroactive forces between oxygen atom with lone pair of electrons on the Ajowan molecules and the electrically charged surface of the steel. The negative sign of free energy of adsorption indicates that the adsorption of Ajowan extract at steel surface is a spontaneous process (L. Tang, X. Lie, Y.Si, G. Mu and G. Liu, 2006) (A. Y. El-Etre, Applied Surface Science, 2006) (Ehteram A. Noor, Int. J. Electrochem.Sci., 2007).

\section{Conclusion}

From the present investigation, the following conclusions can be drawn:

- Ajowan seeds extract was found to be good nontoxic and safe inhibitor for steel corrosion in $2.0 \mathrm{M} \mathrm{H}_{2} \mathrm{SO}_{4}$.

- The chemical and electrochemical measurements showed that inhibition efficiency increased with an increase in Ajowan extract concentration.

- EIS shows that the charge-transfer resistance increases by increasing the concentration of the Ajowan extract, while the capacitance of double layer decreases with increasing the extract concentration.

- The electrochemical results from potentiodynamic polarization indicate that the Ajowan extract affected both anodic and cathodic processes, i.e., Ajowan extract is mixed type inhibitor. 
- The corrosion process is inhibited by adsorption of Ajowan molecules on steel surface following the Freundlish isotherm and the adsorption is physical.

\section{References}

A. Y. Musa, A. A. H. Kadhum, M. S. Takriff, A. R. Daud and S. K. Kamarudin. (2009). Modern Applied Sci.,3(4), 90-94 (2009).

A.M. Abdel-Gaber, B.A. Abd-El-Nabey, I.M. Sidahmed, A.M. El-Zayaday, M. Saadawy. (2006). Corros. Sci. 48, 2765 (2006).

A. Minhaj, P.A. Saini, M.A. Quaraishi. (1999). Corros. Preven. Contr. 46, 32 (1999).

A.Y.E. Etre, M. Abdullah, Z.E.E. Tantawy. (2005). Corros. Sci. 47, 385 (2005).

A. Chetouani, B. Hammouti. (2003). Bull. Electrochem. 19, 23 (2003).

A. Y. El-Etre. (2003). Corros. Sci. 45, 2485 (2003).

A. K. Maayta and N. A. F. Al-Rawashdeh. (2004). Corros. Sci. 46, 1129 (2004).

A. Popova, M.Christov, S. Raicheva and E.Sokolova. (2004). Corros. Sci. 46 (2004) 1333.

A. Y. El-Etre. (2006). Applied Surface Science, 252, 8521-8525 (2006).

B. Abd-El Nabey, E. Khamis, G. Thompson and J. Hames. (1986). Surf. Coat. Technol., 28, 83 (1986).

B. Berge, K. Grijotheim, C. Kronhn, R. Ncumann and K. Torkiep. (1976). Light Metals, (edited by S R Leavitt) Proceeding of 105th annual meeting, 23(1976).

E. Stupnisek-Lisac, K. Salajster and J.Furac. (1988). Corros. Sci., 28, 1189 (1988).

E. E. Ebenso, N. O. Eddy and A. O. Odiongenyi. (2009). Portugaliae Electrochimica Acta, 27(1), 13-22 (2009).

E.E. Oguzie. (2006). Pig. Resin. Tech. 35, 334 (2006).

E. E. Oguzie, G. N. Onuoha and A. I. Onuchukwu. (2004). Mater. Chem. Phys. 89 (2-3), 305 (2004).

E. E. Oguzi. (2005). Mater. Lett. 59, 1076 (2005).

E. E. Oguzi. (2006). Mater. Chem. Phys. 99 (2-3), 441 (2006).

Ehteram A. Noor. (2007). Int. J. Electrochem.Sci., 2, 996-1017 (2007).

F. Zucchi and I. H. Omar. (1985). Surf. Tech. 24, ) 391 (1985.

F. Bentiss, M. Traisnel, H. Vezin and M. Lagrenee. (2000). Eng. Chem. Res. 39, 3732-3736 (2000).

F. Bentiss, M. Lagrenee, M. Traisnel and J. C. Hornez. (1999). Corros. Sci., 55(10), 968 (1999).

F. Mansfeld, M. W. Kending and S. Tsai. (1982). Corrosion, 38, 750 (1982).

G. Gunasekaran and L.R. Chauhan. (2004). Electrochimica Acta 49, 4387 (2004).

G.O. Avwiri, F.O. Igho. (2003). Mater. Lett. 57, 3705 (2003).

K. Anuradha, R. Vimala, B. Narayanasamy, J. Arockia Selvi, S. Rajendran. (2008). Chem. Eng. Comm. 195, 352 (2008).

K. O. Orubite and N. C. Oforka. (2004). Mat. Lett., 58, 1768 (2004).

L.R. Chauhan, G. Gunesekaran. (2007). Corros. Sci. 49, 1143 (2007).

L. Tang, X. Lie, Y.Si, G. Mu and G. Liu. (2006). Mater. Chem. Phys., 95, 29 (2006).

M. Kliskic, J. Rado Sevic, S. Gudic and V. Katalinic. (2000). J. Applied Electrochem. 30, 823 (2000).

M.A.Ameer, E.Khamis and G. Al-Senani. (2000). Adsorpt. Sci. Technol. 18, 177 (2000).

M. Abdallah. (1981). Corros. Sci., 46 (2004) 1981.

M. Kliskic, J. Radosevic, S. Gudic and V. Katalinik. (2000). J. Appl. Electrochem., 30, 823(2000).

P.C. Okafor, E.E. Ebenso. (2007). Pig. Resin. Tech. 36, 134 (2007).

S. Arab and B. Abd-El Nabey. (1991). Int. J. Chem., 2, 23 (1991).

S. Rajendran, S. Vaibhavi, N. Anthony and D.C. Trivedi. (2003). Corrosion 59, 529 (2003).

S. Rajendran, A. John Amalraj, M. Jasmine Joice, Noreen Anthony, D.C.Trivedi and M. Sundaravadiveelu. (2004). Corrosion Reviews 22, 233 (2004). 
S. Rajendran, V. Ganga Sri, J. Arockia Selvi, A.J. Amalraj. (2005). Bull.Electrochem. 21, 367 (2005).

S. Rajendran, S. Shanmugapriya, T. Rajalakshmi, A. John Amalraj. (2005). Corrosion 61, 685 (2005).

S. Rajendran, S. Muthulakshmi, R. Rajeshwari, A. Vijitha. (2005). J. Electrochem. Soc. 54, 50 (2005).

S. Nagalakshmi, N. B. Shankarya, J. P. Naik and L. J. M. Rao. (2000). J. Food Sci. \&Tech., 37(3), 277-281 (2000).

S. Muralidharan, B. R. Babu and S. V. Iyer. (1996). J. App. Electrochem., 26, 291(1996).

T. Arab and A. M. Al-Tukustani. (2002). International J. Chem., 12 (4), 249 (2002).

T. Tsura, S. Haruyama and B. Gijutsu. (1978). J. Jpn. Soc. Corros. Eng., 27, 570 (1978).

Table 1. Corrosion rates obtained from HE and ML for steel in $2.0 \mathrm{M} \mathrm{H} \mathrm{H}_{2} \mathrm{SO} 4$ in absence and presence of different concentrations of Ajowan seeds extract at $30^{\circ} \mathrm{C}$.

\begin{tabular}{|l|l|l|l|l|l|l|}
\hline Cinh.v/v\% & 0.0 & 1.0 & 2.0 & 5.0 & 10.0 & 15.0 \\
\hline $\begin{array}{l}\mathrm{R} \times 10^{2} \\
\left(\mathrm{ml} . \mathrm{cm}^{-2} \mathrm{~min}\right)\end{array}$ & 4.000 & 2.960 & 2.467 & 1.180 & 0.933 & 0.457 \\
\hline $\left.\begin{array}{l}\mathrm{R}^{\prime} \times 10^{5} \\
(\mathrm{~g} . \mathrm{cm} .\end{array}{ }^{-2} \mathrm{~min}\right)$ & 6.673 & 5.911 & 5.222 & 3.330 & 2.248 & 1.952 \\
\hline
\end{tabular}

Table 2. Electrochemical parameters for steel corrosion in $2.0 \mathrm{M} \mathrm{H}_{2} \mathrm{SO}_{4}$ in presence of different concentrations of Ajowan seeds extract at $30^{\circ} \mathrm{C}$.

\begin{tabular}{|c|c|c|c|c|c|c|c|c|}
\hline \multirow{2}{*}{$\begin{array}{l}\mathrm{C} \\
\% \mathrm{v} / \mathrm{v}\end{array}$} & \multicolumn{3}{|l|}{ Impedance } & \multicolumn{5}{|c|}{ Polarization } \\
\hline & $\begin{array}{l}\mathrm{R}_{\text {Sol. }} \\
\text { Ohm cm }\end{array}$ & $\begin{array}{l}\text { Ret } \\
\text { Ohm cm }\end{array}$ & $\begin{array}{l}\mathrm{C}_{\mathrm{dl}} \times 10^{-4} \\
\mathrm{~F}\end{array}$ & $\begin{array}{l}-E_{\text {corr. }} \\
(\mathrm{mv})\end{array}$ & $\begin{array}{l}\mathrm{b}_{\mathrm{a}} \\
\mathrm{V} / \mathrm{dec} .\end{array}$ & $\begin{array}{l}\mathrm{b}_{\mathrm{c}} \\
\mathrm{V} / \mathrm{dec} .\end{array}$ & $\begin{array}{l}\text { Icorr. } \\
\mathrm{mA} / \mathrm{cm}^{2}\end{array}$ & $\begin{array}{l}R_{\text {corr. }} \\
\mathrm{mm} / \text { dey }\end{array}$ \\
\hline 0.0 & 0.939 & 9.134 & 0.205 & 404.16 & 58.408 & 102.57 & 8.0176 & 92.925 \\
\hline 1.0 & 1.217 & 10.32 & 8.770 & 424.66 & 28.567 & 100.52 & 5.1296 & 59.453 \\
\hline 2.0 & 1.190 & 15.94 & 7.104 & 424.31 & 17.346 & 127.23 & 4.6532 & 53.931 \\
\hline 5.0 & 1.040 & 20.28 & 6.078 & 422.10 & 35.662 & 75.909 & 4.0978 & 47.493 \\
\hline 10.0 & 1.442 & 22.67 & 3.449 & 425.15 & 34.689 & 26.474 & 3.4317 & 39.779 \\
\hline 15.0 & 1.278 & 23.39 & 2.302 & 411.46 & 32.357 & 101.08 & 2.4298 & 28.161 \\
\hline
\end{tabular}

Table 3. The inhibition efficiencies (Inh.\%) for steel corrosion in $2.0 \mathrm{M} \mathrm{H}_{2} \mathrm{SO}_{4}$ in presence of Ajowan seeds extract at $30^{\circ} \mathrm{C}$ from different methods.

\begin{tabular}{|l|l|l|l|l|}
\hline \multirow{2}{*}{$\begin{array}{l}\text { I } \\
\% \mathrm{v} / \mathrm{v}\end{array}$} & \multicolumn{3}{l|}{ Inhibition\% } & \multicolumn{3}{l|}{} \\
\cline { 2 - 5 } & Inh.H & Inh.M & Inh.Rct & Inh.P \\
\hline 0.0 & -- & -- & - & -- \\
\hline 1.0 & 26.00 & 11.42 & 11.51 & 36.02 \\
\hline 2.0 & 38.33 & 21.74 & 42.74 & 41.96 \\
\hline 5.0 & 70.50 & 50.10 & 54.98 & 48.89 \\
\hline 10.0 & 76.67 & 66.31 & 59.73 & 57.20 \\
\hline 15.0 & 88.57 & 70.75 & 60.91 & 69.69 \\
\hline
\end{tabular}




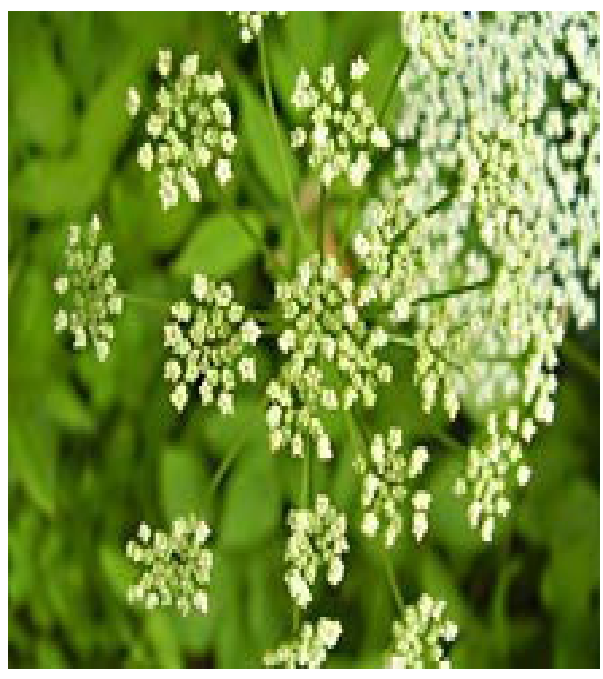

a

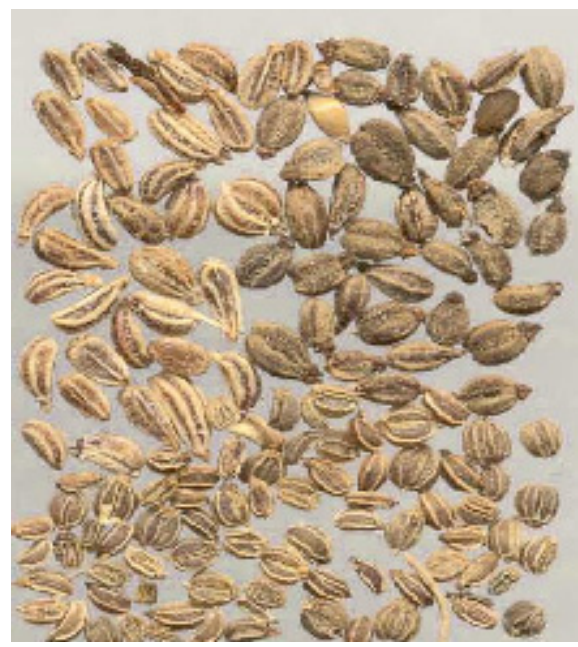

b

Figure 1. Ajowan(carum) plant a)Tree and b)Seeds.<smiles>Cc1ccc(C(C)C)c(O)c1</smiles><smiles>Cc1ccc(C(C)CCl)cc1O</smiles><smiles>Cc1ccc(C(C)C(F)F)cc1</smiles><smiles>CCCCCC(C)C1=CCC(C)=CC1</smiles>

Figure 2. Structure of some Ajowan components. 


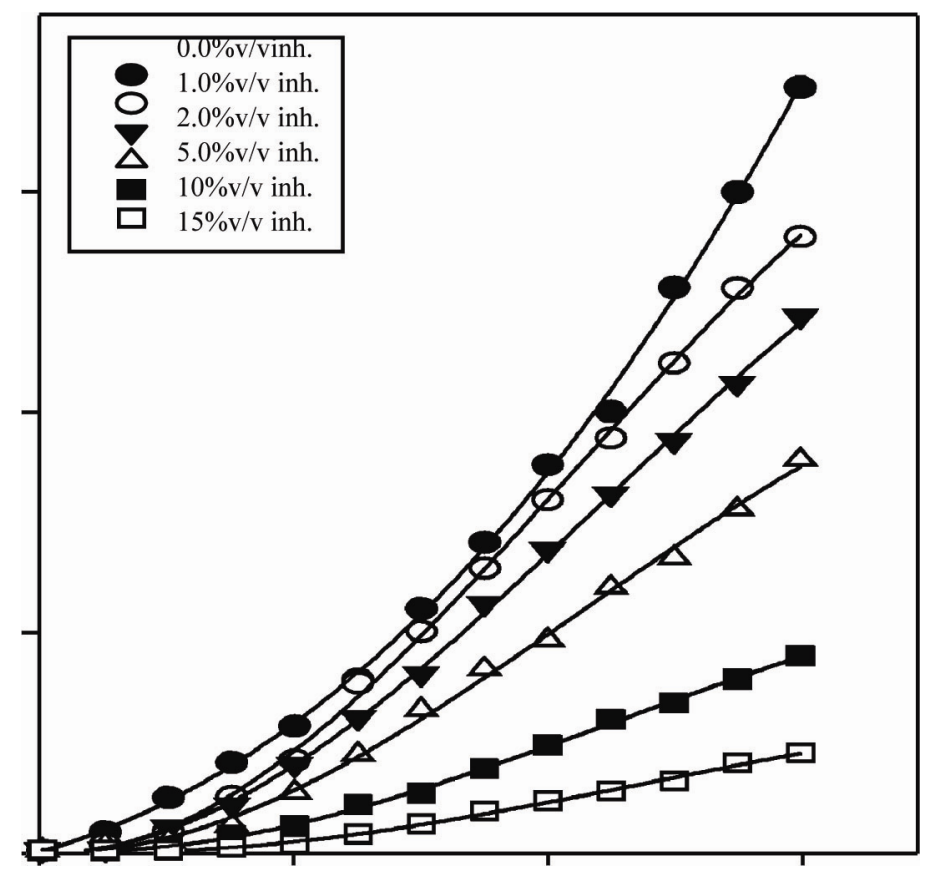

Figure 3. Hydrogen/time curves for steel sample corrosion in $2.0 \mathrm{M} \mathrm{H}_{2} \mathrm{SO}_{4}$ in absence and presence of different concentrations of Ajowan seeds extract at $30^{\circ} \mathrm{C}$.

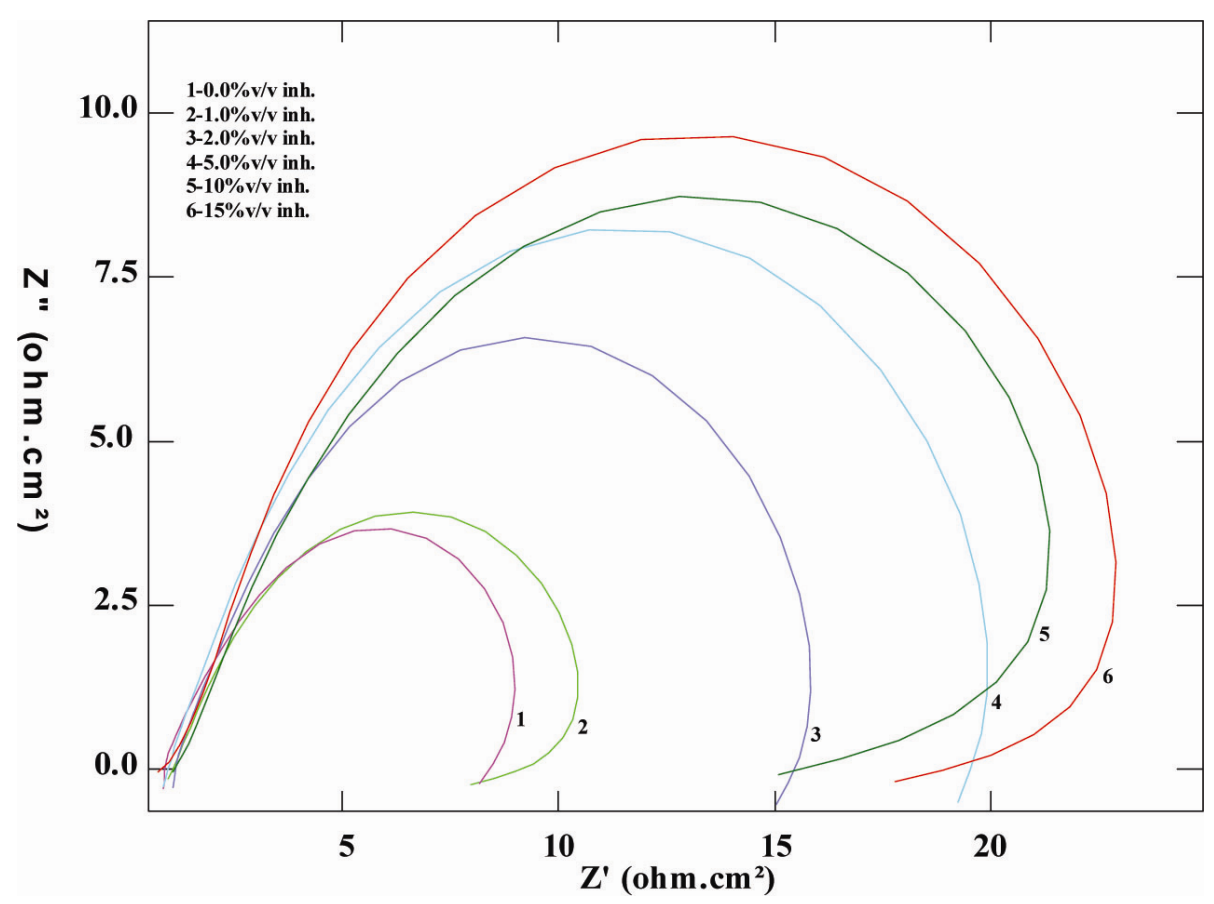

Figure 4. Nyquist plots of steel sample corrosion in $2.0 \mathrm{MH}_{2} \mathrm{SO}_{4}$ in absence and presence of different concentrations of Ajowan seeds extract at $30^{\circ} \mathrm{C}$. 


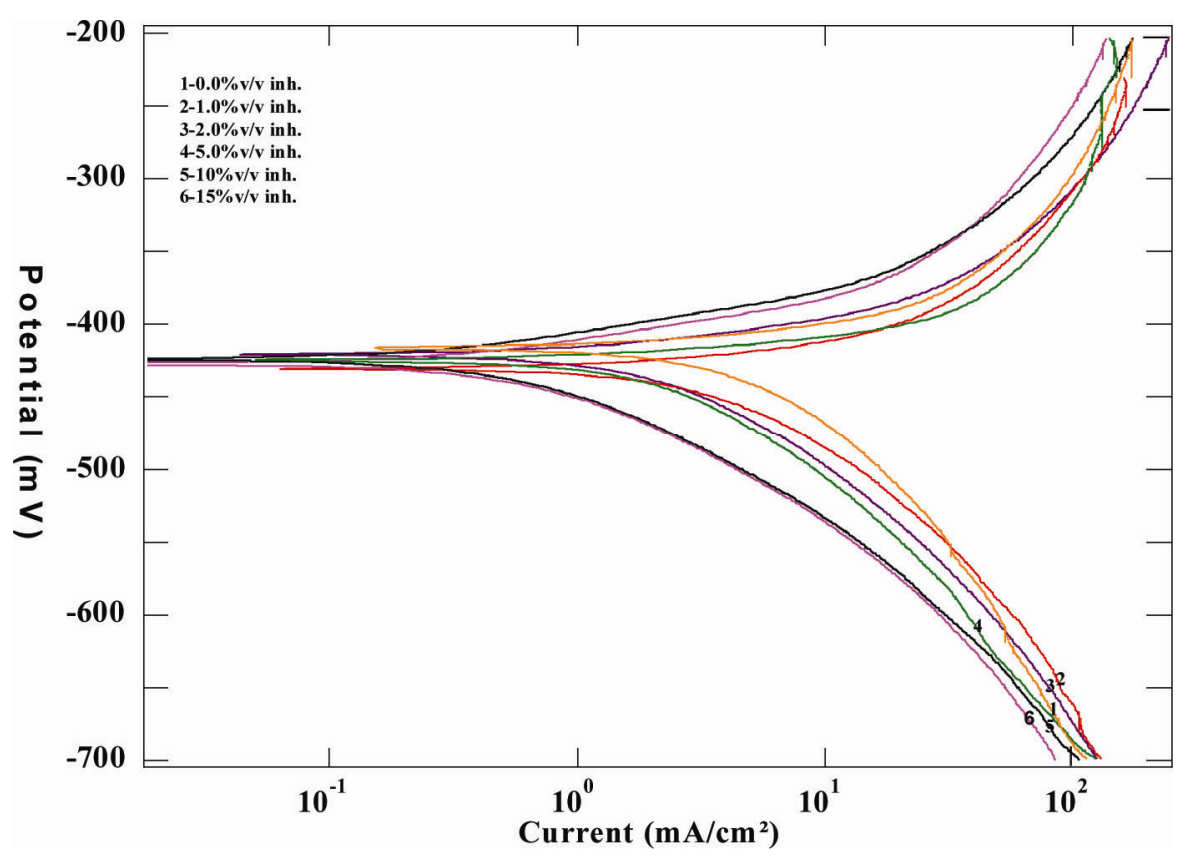

Figure 5. Polarization plots for steel sample corrosion in $2.0 \mathrm{M} \mathrm{H}_{2} \mathrm{SO}_{4}$ in absence and presence of different concentrations of Ajowan seeds extract at $30^{\circ} \mathrm{C}$. 


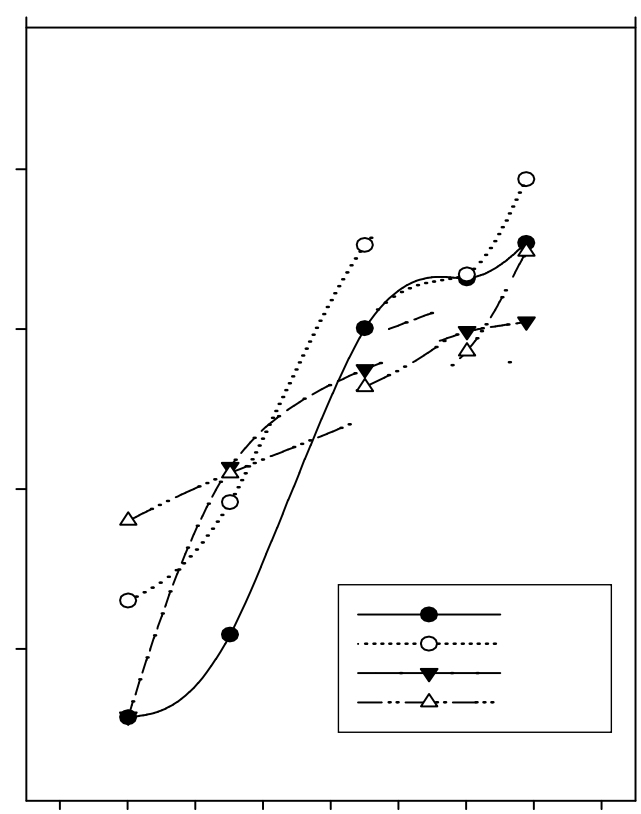

Figure 6. The variation of inhibition efficiency (Inh.\%) against $\log \mathrm{C}_{\text {inh. }}$ for steel corrosion in $2.0 \mathrm{M} \mathrm{H}_{2} \mathrm{SO}_{4}$ at $30^{\circ} \mathrm{C}$.

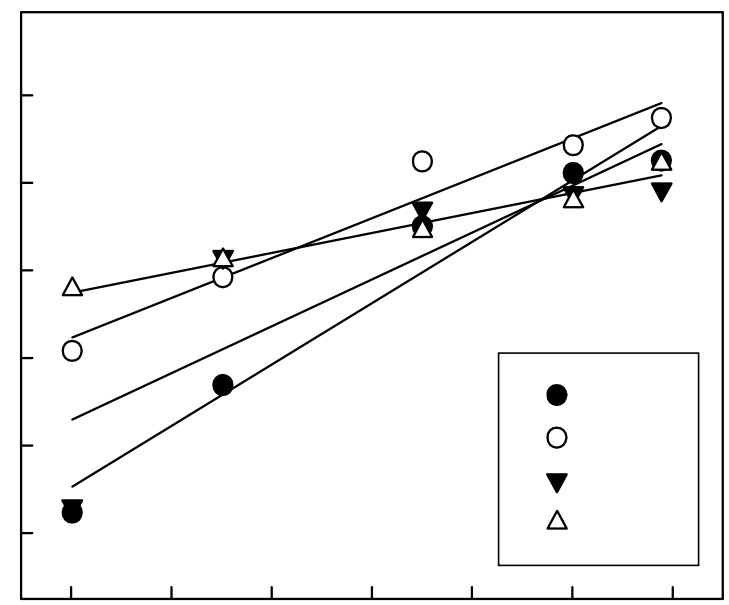

Figure 9. Freundlish adsorption plots for the extract of Ajowan seeds $2.0 \mathrm{M} \mathrm{H}_{2} \mathrm{SO}_{4}$ at $30^{\circ} \mathrm{C}$. 